\title{
Erratum to: Taguchi Method Implementation in Taper Motion Wire EDM Process Optimization
}

\author{
S. Y. Martowibowo $\cdot$ A. Wahyudi
}

Published online: 15 June 2013

(C) The Institution of Engineers (India) 2013

Erratum to: J. Inst. Eng. India Ser. C

(October-December 2012) 93(4):357-364

DOI 10.1007/s40032-012-0043-z

Unfortunately, in the original publication of the article, captions of Figs. 1 and 2 have been swapped. The correct caption for Fig. 1 should be "EDM process" and for Fig. 2 it should read "Wire EDM process."

The online version of the original article can be found under doi:10.1007/s40032-012-0043-z.

S. Y. Martowibowo $(\square)$

Faculty of Mechanical and Aerospace Engineering, Institut

Teknologi Bandung, Jalan Ganesa 10, Bandung 40132,

Indonesia

e-mail: sigit@ftmd.itb.ac.id

A. Wahyudi

PT. Meiwa Mold Indonesia, Block NN-3, MM2100 Industrial

Town, Cibitung, Bekasi 17520, Indonesia 